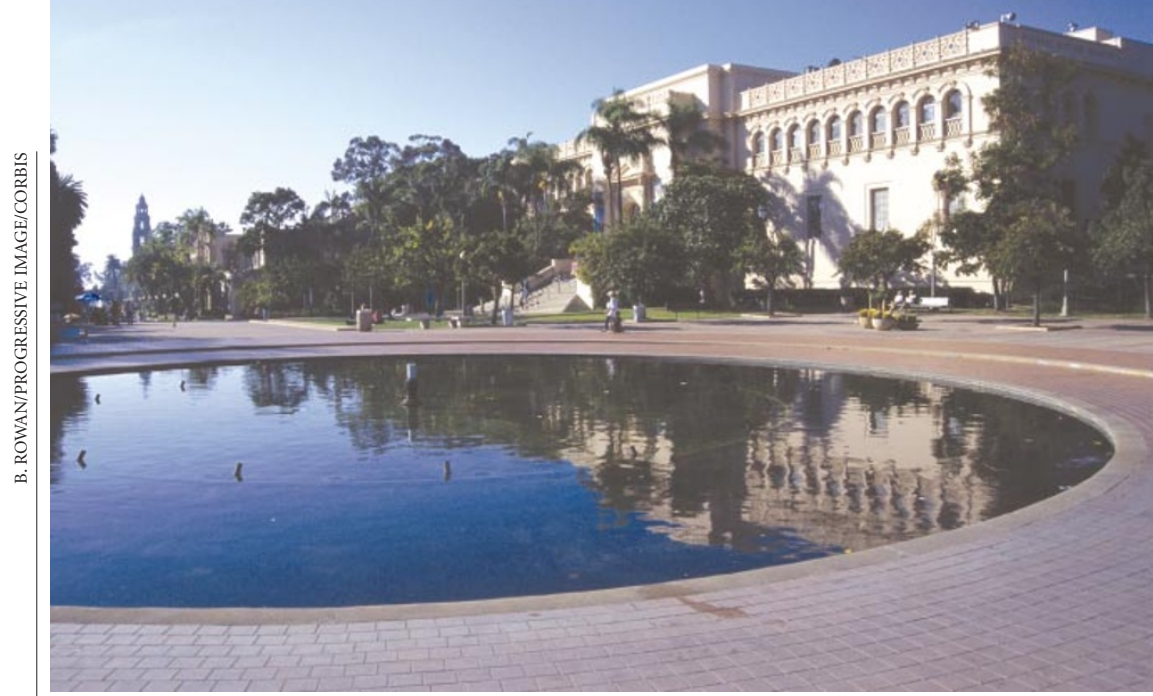

Troubled waters: San Diego's Natural History Museum, like many others, faces a budget crisis.

\title{
Natural history collections in crisis as funding is slashed
}

\section{Rex Dalton, San Diego}

Natural history museums and valuable university collections of plant and animal specimens are being hit hard by the economic climate across the United States, researchers say, threatening a wide variety of research projects.

Curators are being laid off, departments closed, systematic collections dispersed and library subscriptions sliced as administrators seek to make up budgetary shortfalls — often caused by cuts in support from state governments to universities and their museums. Reduced private donations, endowments hit by the stock-market slide and a downturn in revenue from visitors have also hurt.

And programmes are set to suffer more, as state governments try to balance their annual budgets for fiscal years that start in July.

"These collections help us understand the past, and be better stewards of the future," says John Heyning, deputy director for research and collections at the National History Museum of Los Angeles County, and president of the Washington-based National Science Collections Alliance. "But we've done a poor job of speaking in a strong, united voice on our role," he says — leaving collections politically vulnerable in the current climate.

Biologists say that the timing of the crisis is particularly unfortunate because researchers are just becoming able to sequence complete genomes inexpensively - potentially redefining the study of evolutionary biology and of relationships between species.

"Our collection has extraordinary untapped scientific value," says ecologist Michael Rosenzweig, director of the Museum of Natural History at Virginia Tech in Blacksburg. "But we definitely are moving backwards." State budget cuts have forced Virginia Tech to dissolve the museum's 150year-old collection, he says, dispersing the
1.5 million specimens to various departments and institutions.

At the University of Iowa in Iowa City, budget cuts are prompting the closure of the herbarium, part of which is to be sent to Iowa State University in Ames. "This is our tool for teaching students about the environment," complains botanist Diana Horton, the herbarium's director. Its 250,000 specimens "represent the diversity" of our state, she says, noting that its intensive agriculture makes Iowa "the most altered state in the union". Horton describes the decision to get rid of a herbarium that only costs $\$ 25,000$ to maintain each year as "a joke" that is being perpetrated "to give the appearance of saving money".

The University of Nebraska, meanwhile, is looking to cut at least \$1.1 million next year from the \$1.8-million budget of the State Museum in Lincoln, which it runs for the state government. The museum holds 14 million specimens, including a scarab beetle collection on behalf of the Smithsonian Institution. Four out of nine tenured faculty positions at the museum will be eliminated, says entomologist Brett Ratcliffe, its associate research director. Four other tenured professors will be transferred to university departments, he adds.

At the San Diego Natural History Museum, scientists are unable to make full use of a new $\$ 29$-million extension because the museum is running a \$1.1-million deficit on its \$7.5-million budget for this. Nine positions - including key research staff slots - remain vacant, and nine other staff have been laid off.

The future looks bleak to custodians of natural history collections across the country, with most funding bodies in equally dire straits. The treatment of the field is "a slap in the face of the scientific community", says palaeontologist David Gillette, who lost his job at the Museum of Northern Arizona in Flagstaff only last week.

\section{Biologist gets} minimum sentence in 'espionage' case

David Cyranoski, Tokyo

A Japanese biologist arrested two years ago under the US economic espionage act emerged with a light sentence from a courthouse in Cleveland, Ohio, on 28 May.

But the trial has left the researcher's career in ruins - and raised worries about the use of this law against unwitting violators, and its potentially adverse effect on scientific collaboration.

Hiroaki Serizawa, then at the University of Kansas Medical Center, was arrested in May 2001 and charged under the 1996 act with allegedly helping a friend, Takashi Okamoto, by storing DNA constructs and cell lines that Okamoto had taken from his employer, the Cleveland Clinic Foundation (see Nature 411, 225-226; 2001).

Last year the charges against Serizawa were reduced to making "false statements" when questioned by FBI agents in 1999 (see Nature 417, 108; 2002). Serizawa corrected the statements on the same day he made them, the prosecutors conceded.

Serizawa was fined the minimum $\$ \mathbf{5 0 0}$, put on probation for three years, during which his movements within and outside the United States are restricted, and given 150 hours of community service.

This case was the first time that section 1831 of the act - in which the benefactor of the crime is a foreign entity - was invoked, and many scientists and lawyers in Japan and elsewhere questioned its use against Serizawa. Critics of the prosecution view the light sentence - as opposed to dropping charges - as an attempt to save face.

But Serizawa's career prospects remain bleak. Since his arrest in May 2001, his graduate students and assistants have left his laboratory, his university refused him tenure, and the American Cancer Society has terminated his grant. "My career was destroyed by the case," Serizawa told Nature.

He says he would like to continue research, but it will be difficult to find an employer. The National Institutes of Health, for example, will not give grants to people convicted of criminal offences within the past three years, unless they have special dispensation.

The United States is still seeking to extradite Okamoto from Japan. Serizawa claims Okamoto deceived him, and has filed a civil suit in Japan against Okamoto to seek compensation, including \$450,000 for legal fees. 